\title{
Effect of Student Participation in Processed Fishery Technopark on Student Employability Skills
}

\author{
Anggi Nurmalasari, Siti Mujdalipah*, Mustika Nuramalia Handayani \\ Agroindustry Technology Education Study Program \\ Universitas Pendidikan Indonesia \\ Bandung, Indonesia \\ *siti.mujdalipah@upi.edu
}

\begin{abstract}
Employment recruitment by companies currently prioritizes employability skills rather than hard skills abilities. The PSMK Directorate seeks to improve the quality of students in preparing a skilled middle-level workforce through the implementation of technoparks. This study aims to 1) determine the participation of students in the processed fisheries technopark; 2) knowing the level of employability skills of class XII agribusiness processing of fishery products students at SMKN 1 Mundu Cirebon; 3) knowing the effect of student participation in technopark on the employability skills of agribusiness processing of fishery products students at SMKN 1 Mundu Cirebon; This research is a descriptive study with a quantitative approach. The samples of this study were students of class XII agribusiness processing of fishery products SMKN 1 Mundu Cirebon in the 2019/2020 academic year who were tenants of technopark and manager of processed fisheries technopark at SMKN 1 Mundu Cirebon. The data collection technique is done through questionnaires that are distributed using google form. Data analysis using simple linear regression analysis. The results showed that 1 ) the participation of students in the processed fisheries technopark was in the very high category; 2) employability skills of class XII agribusiness processing of fishery products students who take part in technopark is in a very high category; 3 ) there is an effect of student participation in processed fisheries technopark on the employability skills of class XII agribusiness processing of fishery products SMKN 1 Mundu
\end{abstract}

Keywords—employability skills, technopark, student participation

\section{INTRODUCTION}

The condition of employment in Indonesia is still largely dominated by high unemployment. The Central Statistics Agency recorded that the number of open unemployed nationally in February 2019 reached 6.82 million people or $5.01 \%$ of the total workforce. The open unemployment rate for Vocational High Schools (VHS) in February 2019 was still the highest among other education levels, namely $8.63 \%$. This is because the mastery of hard skills (skills), soft skills (work ethic and independence), and communication skills of Vocational High School (VHS) graduates are not in accordance with the demands of the business world or industry, or job opportunities are not sufficient to accommodate all VHS graduates to become possibly the cause of the high number of unemployed in Indonesia [1].

The main challenge faced by business and industry today is the need for a workforce that is competent, trained, and ready to work. One of the characteristics of people who are ready to work is those who have employability skills to help in the work environment. Employability skills are the basic skills every worker in the 21 st century must possess for career success. Employment recruitment by companies currently prioritizes employability skills rather than hard skills abilities [2]. The formation of attitudes that support the aspects of student employability skills requires a massive and comprehensive periodic and continuous process so that VHS graduates can meet the standards needed by the world of work and industry and become a professional workforce [2]. Employability skills needed by workers in the $21 \mathrm{st}$ century are communication skills, collaboration, critical thinking skills, technological skills, and the application of academic skills.

It is time for VHS as a human resource provider in the vocational field to develop the concept of education according to the skills of the 21 st century. Efforts made to improve the quality of students in the $21 \mathrm{st}$ century are through the implementation of teaching factories and technoparks which emphasize learning that is increasingly oriented towards the needs of the industrial world and 21st century skills [3]. Through learning in the work environment, the development of student competencies can be realized so that it is expected to have an impact on vocational students' job readiness [4]. The Directorate of Vocational High School Development takes part by trying to improve the competence and entrepreneurial spirit of VHS graduates through the technopark program.

Technopark at VHS is a form of a container (integrator) to connect between VHS that have implemented the teaching factory program with the industrial world. Technopark not only complements student competencies, but develops character and work attitudes such as discipline, responsibility, honesty, cooperation, and leadership needed by the business world and the industrial world [5]. One of the VHS that has implemented the technopark program is SMKN 1 Mundu Cirebon. The 
Technopark at SMKN 1 Mundu Cirebon was founded in 2018, managed by 11 productive teachers of agribusiness processing fishery products and aquaculture. Technopark SMKN 1 Mundu focuses on processed fishery and aquaculture products. Processed fisheries technopark markets teaching factory products from agribusiness processing of fishery products (APHPi) competency of expertise such as fish dumplings, fish balls, and fish nuggets. This teaching factory product for technopark was made by several APHPi students who had passed the selection to become technopark tenants. In addition to making teaching factory products, students who are technopark tenants carry out the product marketing process outside of school.

Based on the explanation above, providing an evaluation to determine the employability skills of students with the existence of a technopark which was attended by several students of class XII APHPi SMKN 1 Mundu, so this study aims to determine the participation of students in processed fisheries technopark at SMKN 1 Mundu Cirebon, to determine the employability skills of class students. XII competency expertise in Fishery Product Processing Agribusiness (APHPi) SMKN 1 Mundu Cirebon in terms of communication skills; cooperation; critical thinking skills; technological skills; and the application of academic skills and knowing the effect of student participation in technopark on the employability skills of APHPi students at SMKN 1 Mundu Cirebon

\section{METHODS}

\section{A. Research Design}

Research conducted using quantitative descriptive because seen from the data and analysis this research uses a lot of processing numbers.

\section{B. Sample}

The sample in this study were 28 students of class XII agribusiness processing of fishery products SMKN 1 Mundu Cirebon who participated in technopark activities and 2 managers of processed fisheries technopark SMKN 1 Mundu Cirebon.

\section{Research Instrument}

The instrument used in this study was a questionnaire. The questionnaire in this study consisted of two questionnaires, namely a questionnaire for assessing student participation in technopark and a questionnaire for employability skills. Indicators used for assessment of student participation in technopark based on activities carried out in technopark [2]. Meanwhile, the employability skills indicator uses the employability skills indicator for VHS students [3].

\section{Data Analysis}

Data from the questionnaire results were analyzed by calculating the percentage of answers to each questionnaire score. The score interpretation criteria regarding the results of the students' employability skills questionnaire and the student participation questionnaire in the processed fisheries technopark can be seen in Table 1 and Table 2 [6].

TABLE I. INTERPRETATION OF QUESTIONNAIRE SCORE ASSESSMENT STUDENT PARTICIPATION IN TECHNO PARK

\begin{tabular}{|l|l|l|}
\hline \multicolumn{1}{|c|}{ Category } & \multicolumn{1}{c|}{ Score } & \multicolumn{1}{c|}{ Percentage (\%) } \\
\hline Very low & $14.00-24.50$ & $25 \%-43.75 \%$ \\
\hline Low & $24.51-35.00$ & $43.8 \%-62.5 \%$ \\
\hline High & $35.01-45.50$ & $62.6 \%-81.25 \%$ \\
\hline Very High & $45.51-56.00$ & $81.3 \%-100 \%$ \\
\hline
\end{tabular}

TABLE II. INTERPRETATION OF QUESTIONNAIRE SCORE STUDENT EMPLOYABILITY SKILLS

\begin{tabular}{|l|l|l|}
\hline \multicolumn{1}{|c|}{ Category } & \multicolumn{1}{c|}{ Score } & \multicolumn{1}{c|}{ Percentage (\%) } \\
\hline Very low & $27.00-47.25$ & $25 \%-43.75 \%$ \\
\hline Low & $47.26-67.50$ & $43.8 \%-62.5 \%$ \\
\hline High & $67.51-87.75$ & $62.6 \%-81.25 \%$ \\
\hline Very High & $87.75-108$ & $81.3 \%-100 \%$ \\
\hline
\end{tabular}

Analysis of the effect of student participation in processed fisheries technopark on students' employability skills using a simple linear regression test technique. The independent variable (X) in this study is the assessment of student participation in fisheries processing technopark. While the dependent variable (Y) in this study is the students' employability skills. The prerequisite tests for testing the linear regression hypothesis were carried out, namely the normality test and the linearity test.

\section{RESULTS AND DISCUSSION}

\section{A. Student Participation in Processed Fisheries Technopark}

The participation of students in the processed fisheries technopark at SMKN 1 Mundu Cirebon is an independent variable $(\mathrm{x})$. This assessment is carried out using a google form, student scores from manager 1 and manager 2 are averaged so that one score is obtained for each assessment. Assessment data for student participation in processed fishery technoparks can be seen in Figure 1.

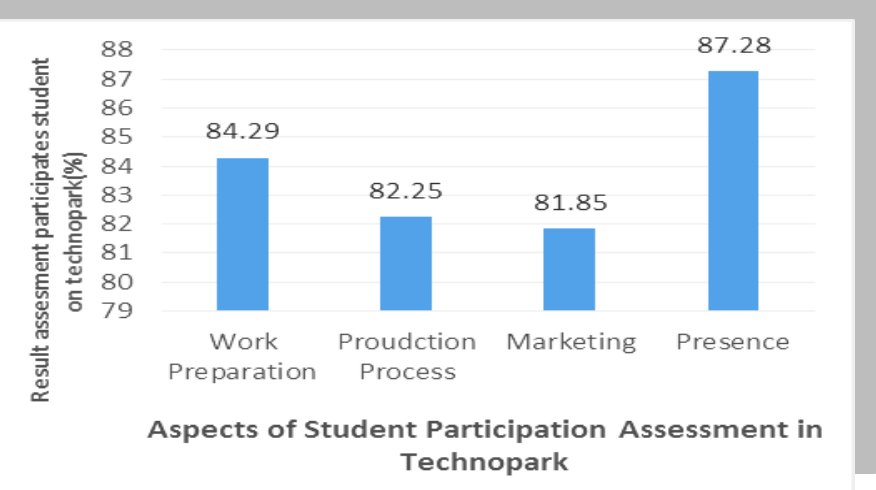

Fig. 1. Results of student participation assessment in fisheries processed technopark 
Overall, the average results of the assessment of student participation in processed fisheries technopark was 46.82 with a percentage of $83.61 \%$. Based on Table 1 . the average results of the assessment of student participation in processed fisheries technoparks are in the very high category, so that on average students participating in processed fisheries technoparks are good and correct following the processed fisheries technopark activities. Based on the results of the questionnaire, the average assessment of students' work preparation before starting the production process was $84.29 \%$. Most of the students have done their job preparation well. Before starting the production process, students prepare themselves by replacing school uniforms with laboratory coats. Students always arrive on time because students at SMKN 1 Mundu Cirebon are very disciplined.

Meanwhile, the results of the questionnaire regarding the results of the assessment of the production process, in general, students have not been able to use a grinding machine. This is consistent with the statement of the fisheries processing technopark technician, that only some students can use the dough rolling machine. The dough rolling machine has a very large and sharp knife so that apart from being done by some students, the milling process is mostly done by technicians because there is a fear of work accidents. Students have also been able to form product dough according to the SOP because students are always taught to form products according to the SOP by the fishery processed technopark manager. Learning is a change in behavior from the results of experience. Learning is the result of an interaction between stimulus (S) and response (R) [7]. The stimulus is given by the manager of processed fisheries technopark to students resulted in students who could form the dough according to the SOP.

Overall, the average results of the student marketing assessment were $81.25 \%$. Marketing is a habit of speaking well. If students are accustomed to speaking words well, interaction with customers can increase [5]. Marketing done by students is a sales promotion using personal selling. Sales promotion is a sales effort that includes marketing communication activities that can stimulate consumer purchases and dealer effectiveness [8]. The marketing ability of students is very high, this is because in the selection test to become a technopark tenant there is a consideration of product marketing skills, so that the average marketing assessment is at a very high level.

\section{B. Student Employability Skills}

Employability skills are closely related to the various skills a person needs, including vocational graduates to be better prepared to enter or get a job. Employability skills in this study are the dependent variable (Y). The data were obtained from filling out a questionnaire by class XII APHPi students of SMKN 1 Mundu Cirebon who became technopark tenants. The data collected from the questionnaire results regarding the students' employability skills can be seen in Figure 2.

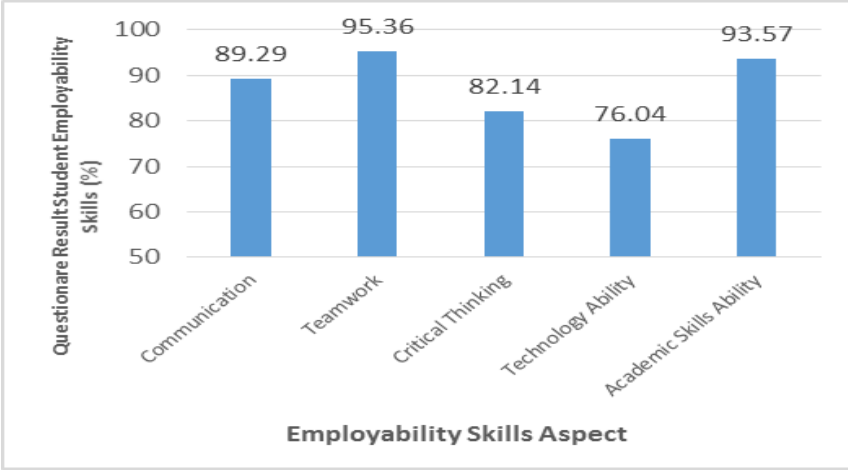

Fig. 2. Results of Student Employability Skills

Overall, the average employability skills of students who took part in processed fisheries technoparks were 93.89 with a percentage of $87 \%$. Based on Table 2 regarding the category of interpretation of the employability skills questionnaire scores, the average employability skills of students who take part in the processed fisheries technopark are in the very high category.

Based on the results of the questionnaire on the communication aspect, students have oral communication skills, writing skills, and listening skills in the very high category. This oral communication ability can be influenced by the activities of students who are followed at school and outside of school. Ability students to written communication skills can be honed through writing reports. Students 'communication skills must be stimulated by learning that can explore the students' abilities [9]. The ability to hear can also be trained, the more listening practice is to be, the better it is in understanding a conversation with other people [10].

Also, students' cooperation ability has an average of 19.07 with a percentage of $95.36 \%$. The ability to cooperate can be improved through group activities. Learning at SMKN 1 Mundu Cirebon is mostly through group activities so that the sub-indicator is willing to work together as a whole is in the very high category. Collaboration in groups can be interpreted as activities to achieve group goals, collaboration in practicum groups is also needed to achieve good learning [11]. Workbased learning can contribute to and influence student collaboration skills [12]. Work-based learning applied at SMKN 1 Mundu is in the teaching factory activities and technopark activities, so that students have a very high level of cooperation in the category.

Overall, the results of filling out the critical thinking ability questionnaire of students who took processed fisheries technopark were $82.14 \%$ in the very high category. This critical thinking category can be seen from the answers to students' statements which refer to the indicators of critical thinking skills. Work-based learning can also improve their critical thinking skills. Students gain experience and learn about how to deal with workplace situations, think creatively to improve the quality of work, and learn to make decisions to solve problems at work [12]. 
Based on the results of the questionnaire, the overall ability to use technology in students who follow processed fisheries technopark is $78.87 \%$. The ability to use technology is a necessity in the era of globalization. The ability to use technology can be trained so that technological capabilities can develop. Computer technology skills at SMKN 1 Mundu Cirebon are trained through digital simulation subjects. The mastery of computer technology in students who take part in technoparks is higher, because in fisheries processing technopark activities, sometimes students also help work using computers.

Based on the results of the questionnaire, the overall ability of students in understanding the process of diversified processed production in students who followed fisheries processing technopark was $92.41 \%$. Learning can be done from the results of exercises or habits of reacting to certain stimuli experienced in his life [13]. The habits carried out by students in processed fisheries technoparks can stimulate or increase understanding of the diversified processed production process.

\section{The Effect of Student Participation in Processed Fisheries Technopark on Students' Employability skills}

Based on the calculation of the statistical analysis of the participation of students in processed fisheries technopark on employability skills, it is obtained that the linear regression equation:

$$
\begin{gathered}
y=10.071+1.728 x \\
\alpha+\beta=\chi .
\end{gathered}
$$

Based equation (1), the constant value of 10.071 means that the consistent value of the student's employability skills variable $(\mathrm{Y})$ is 10.071 . The regression coefficient $\mathrm{X}$ is 1.728 , which means that for every $1 \%$ increase in the value of student participation in the technopark, the value of the students' employability skills increases by 1.728 . The regression coefficient is positive, so it can be said that the direction of the influence of variable $X$ (student participation in processed fisheries technopark) on $\mathrm{Y}$ (student employability skills) is positive. The level of relationship (correlation) between student participation in processed fisheries technopark with students' employability skills is in a fairly strong category with a correlation coefficient of 0.436 . The contribution of students' participation in technopark was $19 \%$ towards the employability skills of class XII APHPi students of SMKN 1 Mundu Cirebon.

Based on these findings, the participation of students in technopark was able to increase students' employability skills by $19 \%$, while the rest was influenced by other factors that were not analyzed in this study. So far, the process of developing soft skills (communication, cooperation, critical thinking) has been carried out in an integrative manner in training, school culture, and extra-curricular activities [14]. Thus, students' employability skills can also be influenced by school culture and extracurricular activities. Employability skills can be developed through academic assignments, work practices, industry-based learning, and work-integrated cooperative learning [15]. Thus, student participation in technoparks can affect students' employability skills because of student activities in processed fisheries technoparks such as work practices and work-related activities.

Employability skills could be increased through the teaching factory program and professional certification [16]. Work-based learning contributes to the development of students' employability skills which include communication skills, collaboration, innovation, self-management, problemsolving skills, and learning skills [17]. Work-based learning is ideal for developing and shaping students' employability skills. Activities carried out by students in technopark such as activities in the teaching factory, students do more vocational training such as the production process so that it affects students' employability skills.

One of the activities at Technopark that increases students' employability skills is product marketing activities. Marketing activities accustom students to communicate well with customers. The learning process in the marketing aspect is a habit of speaking words well. If students are used to speaking words well to their interlocutors, the students' communication skills will increase [5]. Someone who is able to interact with other people in their daily life certainly has higher soft skills in communicating [18]. In addition, in the production process, cooperation is needed to produce a product neatly and correctly, so that students' cooperative habits are developed during the production process.

\section{CONCLUSION}

Employability skills of students in the aspects of cooperation, technological abilities, and application of academic skills are in the high category. Meanwhile, the aspects of communication and critical thinking are in the very high category. There is an effect of student participation in processed fisheries technopark on the employability skills of class XII APHPi SMKN 1 Mundu students. The contribution of the influence of student participation in processed fisheries technopark to employability skills was $19 \%$, while $81 \%$ of the effect came from other factors not examined in this study.

\section{REFERENCES}

[1] A.M. Khoiron, "The Influence of Teaching Factory Learning Mode Implementation To The Students Occupational Readiness", Jurnal Pendidikan Teknologi dan Kejuruan, vol. 23, no. 2, pp. 122-129, 2016.

[2] S. Munadi, Employability skills Lulusan SMK dan Relevansinya Terhadap Kebutuhan Dunia Kerja, Yogyakarta: UNY Press, 2018.

[3] Direktorat Pembinaan Sekolah Menengah Kejuruan, Grand Design Pengembangan Teaching Factory dan Technopark di SMK, Jakarta: Kemendikbud, 2016.

[4] S. Dewi and P. Sudira, "The Contribution of Teaching Factory Program Implementation on Work Readiness of Vocational High School Students In Makassar," Journal of Educational Science anf Technology, vol. 4 no. 2, pp. 126-131, 2018.

[5] F.A. Rizki, "Pengaruh Keikutsertaan Siswa Dalam Unit Produks Terhadap Kesiapan Kerja Siswa Teknologi Hasil Pertanian (THP) di Bidang Agroindustri," unpublished. 
[6] S. Akbar, Instrumen perangkat pembelajaran, Bandung: Remaja Rodaskarya, 2013

[7] N.I. Nahar, "Penerapan teori belajar behavioristik dalam proses pembelajaran," NUSANTARA: Jurnal Ilmu Pengetahuan Sosial, vol. 1, no. 1, pp. 64-74, 2016.

[8] W.P. Widharta and S. Sugiharto, "Penyusunan Strategi dan Sistem Penjualan Dalam Rangka Meningkatkan Penjualan Toko Damai," Jurnal Manajemen Pemasaran Petra, vol. 2, no. 1, pp. 1-15, 2013.

[9] I. Suyana, L. Amalia, and A. Setiawan, "Upaya Meningkatkan Kemampuan Komunikasi Dan Pemahaman Konsep Siswa Melalui Pembelajaran Inkuiri Berbantu Teknik TSTS (Pada Materi Gerak Lurus di SMAN 6 Bandung)," WaPFi (Wahana Pendidikan Fisika), vol. 2, no. 2, pp. 27-31, 2017.

[10] A.W. Sari, "Pentingnya Ketrampilan Mendengar dalam Menciptakan Komunikasi yang Efektif," EduTech: Jurnal Ilmu Pendidikan dan Ilmu Sosial, vol. 2, no.1, pp. 1-10, 2016.

[11] A.R. Putri, M. Maison, and D. Darmaji, "Kerjasama dan Kekompakan Siswa dalam Pembelajaran Fisika di Kelas XI MIPA SMA Negeri 3 Kota Jambi," EduFisika: Jurnal Pendidikan Fisika, vol. 3, no. 2, pp. 3240, 2018.

[12] S. Subekti, "The Implementation of Work-Based Learning for the Development of Employability skills of Vocational Secondary School Students Through Teamwork Activity", Innovation of Vocational Technology Education, vol. 15, no. 1, pp. 35-42, 2019.
[13] M.S. Hanafy, "Konsep belajar dan pembelajaran," Lentera Pendidikan: Jurnal Ilmu Tarbiyah dan Keguruan, vol. 17, no.1, pp. 66-79, 2014.

[14] S. Utaminingsih, "Pengembangan Soft Skill Berbasis Karir pada SMK di Kota Semarang," Dinamika Pendidikan, vol. 6, no. 2, pp. 119-133, 2011.

[15] S. Sunardi, P. Purnomo, and E. Sutadji, "Pengembangan Employability skills Siswa SMK ditinjau dari Implementasi Pendekatan Saintifik," Jurnal Pendidikan: Teori, Penelitian, dan Pengembangan, vol. 1, no. 7, pp. 1391-1398, 2016.

[16] S. Sulistiani and B. Yulianto, "Employability skills of Vocational Graduates: Implementation of Curriculum IQF Level 2," International Conference on Education Innovation (ICEI 2019). Atlantis Press, vol. 387, pp. 6-10, 2019.

[17] S. Subekti, A. Ana, and M. Muktiarni, "Developing Employabilty Skills Using the Work-Based Learning Model" International Conference on Education, Science and Technology. Redwhite Press, vol. 2, pp. 36-42, 2019.

[18] M.N. Wahyu, S. Sutiarso, and H. Bharata, "Pembelajaran Soft Skill Komunikasi untuk Meningkatkan Kemampuan Komunikasi Matematis Siswa," Jurnal Cendekia: Jurnal Pendidikan Matematika, vol. 4, no. 1, pp. 406-413, 2020. 